\title{
Links between tree structure and functional leaf traits in the tropical forest tree Dicorynia guianensis Amshoff (Caesalpiniaceae)
}

\author{
Jean Christophe RogGY ${ }^{a *}$, Eric NiCOLINI ${ }^{\mathrm{b}}$, Pascal IMBERT ${ }^{\mathrm{a}}$, Yves CARAGLIO ${ }^{\mathrm{b}}$, \\ Alexandre BOSC ${ }^{a}$, Patrick HEURET ${ }^{b}$ \\ ${ }^{\text {a }}$ UMR CIRAD-ENGREF-INRA Écologie des Forêts de Guyane, campus agronomique de Kourou, BP 709, 97387 Kourou Cedex, \\ Guyane francaise, France \\ ${ }^{\mathrm{b}}$ UMR AMAP, TA40/PS2, boulevard de la Lironde, 34398 Montpellier Cedex 05, France
}

(Received 1st July 2004; accepted 15 February 2005)

\begin{abstract}
This study looked at the interactive effects of tree architectural stage of development (ASD) and light availability on different plant traits (growth parameters, leaf morpho-anatomy and photosynthetic capacities) in the tropical species Dicorynia guianensis. A qualitative architectural analysis was used to categorize tree individuals sampled along a natural light gradient. The results show that some traits could have an ASD-dependence at the whole plant and leaf level without control of light. The changes observed relate to vigour thresholds the plant has to reach to shift from one ASD to another (i.e., the number of nodes and the internodes length per Growth Unit). Light conditions do not modify these thresholds but may modify the time they are crossed. Tree height was found strongly modulated by light conditions; hence, at a similar height, individuals may belong to different ASD. At the functional level, a decrease in $N_{\mathrm{m}}$, and $A_{\text {maxm }}$ was observed with increasing light availability, while $N_{a}$ increased and $A_{\text {maxa }}$ remained unaffected. An ASD effect was also observed on $A_{\operatorname{maxa}}$ and $L M A$ but not on $A_{\text {maxm}}$. These results demonstrated a weak ability of photosynthetic plasticity in response to light conditions, and that variations of leaf photosynthetic variables according to ASD can be explained by modifications in leaf nitrogen and LMA. Questions on the reliability of a height-based sampling strategy for evaluating the phenotypic plasticity of trees in relation to light conditions are raised.
\end{abstract}

Dicorynia guianensis / leaf structure / functional leaf traits / plasticity / tree structure

Résumé - Relations entre architecture des arbres et traits fonctionnels foliaires de l'angélique Dicorynia guianensis Amshoff (Caesalpiniaceae) en forêt tropicale humide. Les relations entre stades architecturaux de développement (ASD), morpho-anatomie foliaire et capacités photosynthétiques ont été étudiées chez Dicorynia guianensis, une espèce forestière de Guyane. Les ASD ont été définis à l'aide de critères qualitatifs par une méthode simple de description architecturale puis échantillonnés le long d'un gradient naturel de lumière. Les résultats montrent que chaque ASD peut être identifié par un syndrome de caractères quantitatifs. Ces caractères évoluent d'un stade à l'autre, et dans les différents milieux, selon une séquence ordonnée d'événements qui se manifestent pour des seuils de vigueur donnés. Les conditions lumineuses ne modifient pas ces seuils mais avanceraient ou différeraient dans le temps leur passage. La hauteur des individus et le LMA sont fortement modulés par la lumière. Ainsi, pour une même hauteur, des individus peuvent correspondre à des ASD variés. Au niveau fonctionnel, l'augmentation du rayonnement incident s'est traduite par une diminution de $N_{\mathrm{m}}$, et de $A_{\text {maxm }}$ et par une augmentation de $N_{\mathrm{a}}$, tandis que $A_{\text {maxa }}$ n'a pas été affectée. Un effet marqué de l'ASD a été constaté sur $A_{\operatorname{maxa}}$ et LMA mais pas sur $\mathrm{A}_{\operatorname{maxm}}$. Ces résultats révèlent une faible plasticité photosynthétique chez $D$. guianensis et montrent que les variations des capacités photosynthétiques en fonction des ASD sont surtout liées à des variations de $N_{\mathrm{m}}$ et LMA.

Dicorynia guianensis / structures foliaires / traits fonctionnels foliaires / plasticité / structure de l'arbre

\section{INTRODUCTION}

Plant architectural analysis consists of a structural description of individuals that have reached various degrees of development in diverse environmental conditions [9, 10, 33]. This approach is used to identify invariant characters specific for each of the developmental stages that a plant reaches, from germination to senescence (e.g., "the sequence of differentiation"). In this type of analysis, qualitative and/or quantitative changes in tree development are described. These changes may be simultaneously studied on elementary entities corresponding to different levels of organisation within the plant (i.e., metamers, growth units, axes, ... [8]). Chronological successive key stages of development can thus be defined with respect to the degree of complexity of the plant structure or/and to the expression of events like branching, reiteration or sexuality [9, 31]. Recently, some studies have shown that, according to the environmental conditions, a specific stage could be reached at varying dimensions of the individual trees (total height or basal diameter $[49,31,51])$.

\footnotetext{
* Corresponding author: roggy.j@ cirad.fr
} 
The morphological and/or anatomical properties of the elementary entities evolve qualitatively or quantitatively from one development stage to another $[9,49,52]$. At the scale of the metamer for example, leaf structure is a reliable marker of the different stages $[3,65]$, and provides a means for estimating the plant differentiation level or, in other words, its "physiological age" [4]. Nicolini and Chanson [52] have pointed out the relationships between the developmental stages of beech trees (Fagus sylvativa L.) and their foliar anatomy and morphology (i.e., leaf width, mesophyll ratio, leaf mass area, ...). These authors have suggested that leaf traits changed with the successive physiological ages of trees during ontogenesis.

The contribution of the structure to leaf functions is well documented $[32,81]$. Leaf anatomy and morphology, particularly the stomatal density and the shape of the mesophyll air spaces, affect the resistance to gas-exchange and may thus enhance or limit photosynthetic activities [81, 84]. Leaf traits are known to change with plant age $[37,59]$. In some conifer species, Niinemets [57] has observed an increase in the leaf mass per unit area, a decrease in the mass-based leaf nitrogen content and a decrease in the mass-based rates of photosynthesis. Leaf traits are also known to change in responses to light environments and vary widely within and among species $[16,17,24,55,66$, $76,86]$. In general, shade-growing leaves are thinner, with lower leaf mass per unit area and higher chlorophyll content than sun-growing leaves [70].

To date, the application of architectural analysis in ecological and ecophysiological research is still relatively rare [15, 53]. In this paper our objectives were to check for interactive effects of developmental stage and light availability on tree structure and leaf traits in a tropical canopy tree of French Guiana, Dicorynia guianensis Amshoff (Caesalpiniaceae) along a natural light gradient. Five stages of development were considered under three levels of irradiance.

\section{MATERIALS AND METHODS}

\subsection{Study site}

The study was carried out in the northern part of French Guiana in South America ( $5^{\circ} 20^{\prime} \mathrm{N}, 52^{\circ} 50^{\prime} \mathrm{W}$ ) from July to August 2000, in the experimental rainforest of Paracou (CIRAD-Forêt; see description in Bariteau and Geoffroy [7]) and in a nearby clearing. Soils are oxisoils (Keys to Soils Taxonomy, Cornell University, 1985, Ithaca NY, USA) developed on migmatite and shales. In the first zone, $60 \%$ of the tree species belong to only 3 families: Lecythidaceae, Caesalpiniaceae and Chrysobalanaceae [25]. The climate is characterised by a distinctly seasonal pattern: a wet season from December to August, interrupted during February by a short dry season, and followed by a long dry season from September to November. Average annual precipitation is $2500 \mathrm{~mm}$ and mean temperature is $26^{\circ} \mathrm{C}$ with little seasonal change [38].

\subsection{Selection of trees according to the architectural development stage}

The species Dicorynia guianensis Amshoff was chosen as it is relatively abundant and able to establish in the understorey and in clearings (hemitolerant species, [25]). Five successive architectural stages of development (ASD) were chosen (Fig. 1). They are representative for the sequence of differentiation of the species. This sequence was previously defined by Drénou [20] and Nicolini et al. [53] on 1650 trees, by using a simple method of architectural description:

ASD Stage 1: seedlings with unbranched main stem (order 1 axis, A1) and simple leaves on the last nodes.

Stage 2: saplings with unbranched first order axes bearing compound leaves with 7 leaflets on the last nodes.

Stage 3: small vegetative trees with sparsely branched A1 (order 2 axis, A2). The A2 remain unbranched, with a plagiotropic growth. All the axes normally bear compound leaves with seven leaflets, but leaves with nine leaflets may appear on the main axis of some trees.

Stage 4: immature tall trees with an abundantly and regularly branched A1 axis. Three types of secondary axes are present. At the base of the crown, A2 are of "sequential" type [8] (Fig. 1, diamond) with a horizontal main axis turning up in its extremity and carrying small unbranched axillary $A 3$. In the median part of the crown, $A_{2}$ are of "reiterated" type [8] (Fig. 1, cross) with strong turning up and carrying (i) small unbranched axillary A3, (ii) more developed branched axillary $\mathrm{A} 3$ which structure remains close to that of the $\mathrm{A}_{2}$ axis which carries them. At the top of the crown, $\mathrm{A}_{2}$ form large "reiterated complexes" (Fig. 1, circle). They are vertical and reproduce the architectural model of the main axis contributing to the formation of forks. Leaves are always compound with seven leaflets. This stage corresponds to the "architectural metamorphosis" [10] during which the tree changes from a system organised around a single main axis to a system organised around several major branches.

Stage 5: mature adult trees with large trunk, without "sequential" branches and ended by a fork with several reiterated branches. The crown is formed by numerous reiterated complexes displaying a regular structural reduction from the base to the uppermost part of the tree and an increasing degree of sexualization. Sexuality is characterised by terminal inflorescences. The organisation of inflorescences and vegetative structures of reiterated complexes from the peripheral part of an old tree crown is shown in Figure 1. Compound leaves with seven leaflets are mostly found on axes.

\subsection{Tree sampling in different irradiance microenvironments}

Trees corresponding to ASDs 1, 2 and 3 were sampled in two contrasting light environments (understorey and clearing). Individuals belonging to ASDs 4 and 5 were sampled among canopy or emergent trees (the "architectural metamorphosis" only occurs when the trees have reached the canopy). Light microenvironment was quantified in order to select individuals subjected to the most homogeneous light conditions in each treatment. Photosynthetic photon flux density (PPFD) was measured using amorphous silicon quantum sensors (PAR/CBE 80 Solems S.A., Palaiseau, France) calibrated against a LiCor quantum sensor (LI-190 SB, LiCor Inc., Lincoln, NE). The sensors were monitored with battery-operated dataloggers (CR21X Micrologger, Campbell Scientific Inc., Logan, UT). The loggers were programmed to scan each sensor at $1.5 \mathrm{~s}$ intervals and log the data as histograms at $2 \mathrm{~h}$ intervals between 0615 and $1815 \mathrm{~h}$ solar time over 30 consecutive days from July 20 till August 18, 2000. The histograms stored the frequency distribution of PPFD in $50 \mu \mathrm{mol} \mathrm{m}^{-2} \mathrm{~s}^{-1}$ bins between 0 and $50 \mu \mathrm{mol} \mathrm{m}-2 \mathrm{~s}^{-1}$ and in $100 \mu \mathrm{mol} \mathrm{m} \mathrm{m}^{-2} \mathrm{~s}^{-1}$ bins between 50 and $2050 \mu \mathrm{mol} \mathrm{m} \mathrm{m}^{-2} \mathrm{~s}^{-1}$. PPFD was simultaneously recorded for the individuals in the understorey and in clearing (ASD 1,2 and 3) by placing three light sensors above the sampled leaves. One light sensor was also placed at the top of the tree crown of one individual of the ASD 4 and one sensor at the height of $40 \mathrm{~m}$ corresponding to the ASD 5 (emergent tree, full sun reference sensor). A scaffold provided access to the top of the crown. For each individual we calculated the average daily PPFD $\left(\mathrm{mol} \mathrm{m}^{-2} \mathrm{~d}^{-1}\right)$.

Three levels of light availability were found, with a fairly uniform distribution of the PPFD over the different ASD in each environment 

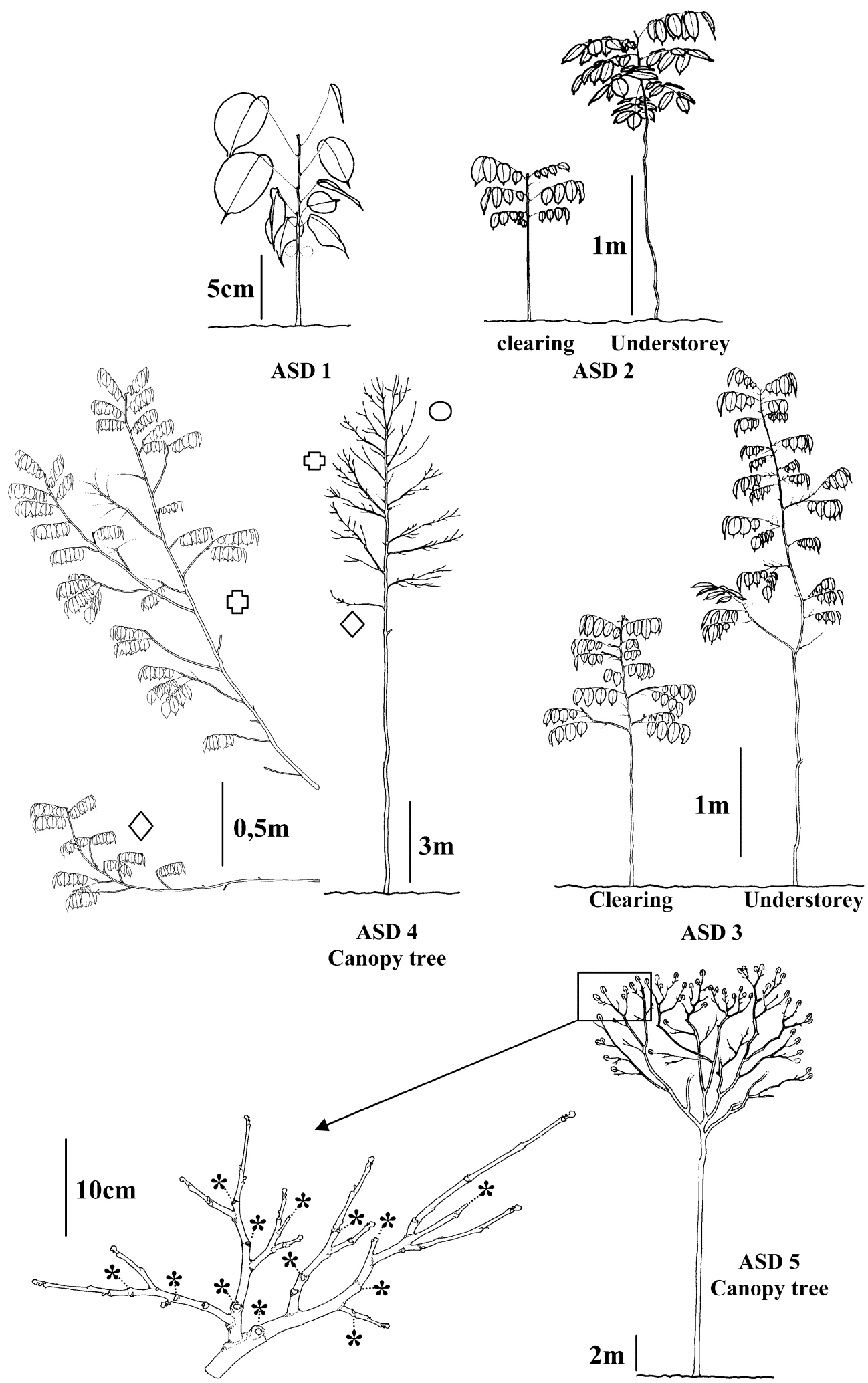

Figure 1. The architectural stages of development (ASD) of Dicorynia guianensis in three contrasting light environments (forest understorey, forest canopy and clearing). Stage 1: seedling; Stage 2: sapling; Stage 3: small juvenile tree; Stage 4: tall juvenile tree in the forest canopy (diamond: sequential axes; cross: reiterated axes; circle: axes of "large reiterated complexes" type); Stage 5: adult canopy tree (the organization of flower-bearing and vegetative structures of reiterated complexes from the peripheral part of the tree crown is shown). For a complete description of the ASD, see Materials and methods. 
Table I. Light micro-environment of trees sampled at different architectural stages of development (ASD) ${ }^{1}$ and growing in the forest (understorey and canopy) and in a clearing. Mean values $( \pm$ SD) of daily total Photosynthetic photon flux densities received on an horizontal surface (PPFD). Means with the same letter were not significantly different $(p>0.05)$. Multiple contrasts were analysed using the Tuckey's HSD test after an one-way ANOVA of Kruskal-Wallis.

\begin{tabular}{|c|c|c|c|}
\hline Environment & & ASD & $\begin{array}{c}\text { Total PPFD } \\
\left(\mathrm{mol} \mathrm{m}^{-2} \mathrm{~d}^{-1}\right)\end{array}$ \\
\hline \multirow[t]{6}{*}{ Forest } & Understorey & 1 & $1.4 \pm 0.3^{\mathrm{a}}$ \\
\hline & & 2 & $1.8 \pm 0.6^{\mathrm{a}}$ \\
\hline & & 3 & $1.5 \pm 0.4^{\mathrm{a}}$ \\
\hline & Canopy & 4 & $37^{\mathrm{b}}$ \\
\hline & & 5 & $37^{b}$ \\
\hline & & 1 & $26.2 \pm 3.8^{c}$ \\
\hline \multirow[t]{2}{*}{ Clearing } & & 2 & $22.3 \pm 2.2^{c}$ \\
\hline & & 3 & $26.2 \pm 3.4^{c}$ \\
\hline
\end{tabular}

${ }^{1}$ For the description of the ASD, see Materials and methods.

(Tab. I). PPDF was lowest in the understorey and intermediate in the clearing, with approximately $3 \%$ and $60 \%$ of the total irradiance, respectively. Hence, for a similar ASD (stages 1, 2 and 3), 5 shadeand 5 light-growing individuals were selected. For the ASD 4 and 5, 5 individuals per ASD were sampled.

\subsection{Quantitative study of the developmental sequence of trees}

D. guianensis displays a rhythmic primary growth [20]. Growth Units (GU, [33]) set up during each period of meristem activity were retrospectively localised along axes by means of morphological markers [53]: variation of bark colour, decrease of internode size and decrease of axes and pith diameter in zones where the growth had temporarily stopped. For each individual, total number of nodes and internode length of the last four GUs on the main axis were measured. Total height $(\mathrm{H})$ and basal diameter (D) of the trees were also measured. Gasexchange was always recorded on the last leaf of the last GU of the main axis, and the structure of the leaves was analysed. Thus, leaves at identical physiological ages were compared $[9,13]$.

\subsection{Gas-exchange measurements}

Prior to harvesting, gas-exchange was measured on the last leaflet of each sampled leaf (one leaflet per individual). A $30 \mathrm{~m}$ high scaffold was used to provide access to the leaves of one canopy tree and gasexchange rates were compared on intact and cut branches. Since similar rates were recorded, the fully expanded leaves from the other canopy trees were shot with a rifle, and the gas-exchange measurements were made, at the feet of the trees, on cut branches kept with the twig under water to avoid embolism in the xylem vessels.

Light-response curves of net $\mathrm{CO}_{2}$ assimilation rates (A-PPFD) were measured using a portable infrared gas-exchange system (CIRAS-1, PP-Systems, Hitchin, UK) with a Parkinson leaf chamber $\left(2.5 \mathrm{~cm}^{2}\right)$. The light was provided by a halogen bulb (Philipps 12V, $20 \mathrm{~W}$ ). The measurements were carried out in the morning between 0700 and $1200 \mathrm{~h}$ in the forest understorey and between 0700 and $1000 \mathrm{~h}$ in the clearing to avoid a mid-day stomatal closure. During the A-PPFD responses, the mean $( \pm \mathrm{SD}) \mathrm{CO}_{2}$ mole fraction was $363 \pm 3 \mu \mathrm{mol} \mathrm{mol}^{-1}$, the air temperature in the leaf chamber and the air water vapour pres- sure deficit at the leaf surface were $29 \pm 1.5{ }^{\circ} \mathrm{C}$ and $1.6 \pm 0.2 \mathrm{kPa}$, respectively. Each A-PPFD curve consisted of eight measurements at decreasing PPFD obtained by placing neutral filters between the bulb and the cuvette: values close to $1050,700,400,150,100,50,30$ and $0 \mu \mathrm{mol} \mathrm{m}{ }^{-2} \mathrm{~s}^{-1}$ were used. The time needed for photosynthetic induction and foliage acclimation between two measurements was about $15 \mathrm{~min}$ [74] and $5 \mathrm{~min}$, respectively.

A non-linear least squares regression (Newton method, ProcNLIN, SAS v.8.1, SAS Institute Inc., Cary, NC) was used to fit A-PPFD curves to the empirical equation of Hanson et al. [34]:

$$
A=A_{\operatorname{maxa}}\left(1-\left(1-R_{d} / A_{\operatorname{maxa}}\right)^{1-Q / Q c}\right)
$$

where $R_{d}$ is the dark respiration (measured at PPFD $=0$ after $5 \mathrm{~min}$ for foliage acclimation), $Q$ is the quantum flux density, $Q c$ is $Q$ at $A=0$ and $A_{\text {maxa }}$ is the light-saturated rate of photosynthesis per unit leaf area.

\subsection{Leaf structure}

The area of each harvested fresh leaf was measured using an electronic area meter (LiCor 3000A, LiCor Inc., Lincoln, NE). Leaf dry mass was measured and the total nitrogen content per unit leaf dry mass $\left(N_{\mathrm{m}}\right)$ was determined with an elemental analyser (SCA, CNRS Solaize, France). Leaf mass per unit leaf area (LMA), nitrogen content per unit leaf area $\left(N_{\mathrm{a}}\right)$, and light-saturated rate of photosynthesis per unit leaf area $\left(A_{\text {maxa }}\right)$ and dry mass $\left(A_{\text {maxm }}\right)$ were calculated. A piece of lamina of each leaf $\left(1 \mathrm{~cm}^{2}\right.$, three replicates per sample) was fixed (5 days in $20 \mathrm{~mL}$ paraformaldehyde $10 \%, 2 \mathrm{~mL}$ glutaraldehyde $50 \%$, $1 \mathrm{~g}$ caffeine $1 \%, 50 \mathrm{~mL}$ buffer $\mathrm{Na}_{2} \mathrm{HPO}_{4}^{+} \mathrm{NaH}_{2} \mathrm{PO}_{4} 7 \%$ and distilled water qsp $100 \mathrm{~mL}$ and then transferred to $70 \%$ aqueous ethanol) for the histological analyses. The samples were then dehydrated in an ethanol series $(70 \%, 90 \%, 100 \%)$ and embedded in resin (Technovit 7100 , KULZER, Germany). The sections were cut at $3 \mu \mathrm{m}$ with a LKB Historange Microtome and stained by astra blue-basic fushin. Quantitative anatomical measurements were made using an image analysis software (Optilab Pro) attached to a standard light microscope (DMPXA, Leica). From these variables, the following parameters were estimated: leaf thickness (T) and leaf density (D), calculated by dividing LMA by thickness [90], and anatomy (volumetric tissue fraction of the palisade (PM) and the spongy (SM) mesophyll, the lower (LE) and the upper (UE) epidermis and the intercellular free air space (FAS). Stomatal densities were estimated under an optical microscope by using epidermal prints on a sheet of rhodoïd soaked with acetone (three replicates per sample).

\subsection{Statistical treatment of data}

Three levels of light availability were found at sites where individuals were sampled (Tab. I; low, medium or high light). We made comparisons between the light classes within ASD 1, 2 and 3 (low light vs. medium light), between ASD 4 and 5 (high light only) and between all ASD, regardless of light availability. In the first case, the effects of light availability and ASD on the whole plant and the leaf variables were assessed with an analysis of variance (factorial ANOVA, PROCGLM SAS v. 8.1, SAS Institute Inc., Cary, NC). The data were ranked to avoid the assumptions of normality [28], and the differences between the means were tested with the multiple comparison post-hoc test of Tukey at $p<0.05$. In the second case, the differences between the means were analysed with the Mann-Whitney U-test $(p<0.05)$ after a one-way ANOVA of Kruskal-Wallis. In the third case, because the sample design was not a full factorial, a two-way ANOVA followed by pre-planned contrasts was performed to compare all ASD in all light environments. Box plots were used to show the variations in the plant variables. 
Table II. Results of the two-way ANOVA testing, the effects of light availability and architectural stage of development (ASD 1, 2 and 3) ${ }^{1}$ on leaf and whole plant variables of Dicorynia guianensis. Data were ranked prior to analysis to avoid assumptions of normality. $F$-values, level of significance $(p)$ are given. Significant levels: ns; $p>0.05$; $* p<0.05 ; * * p<0.01 ; * * * p<0.001 ; * * * * p<0.0001$.

\begin{tabular}{|c|c|c|c|c|c|c|}
\hline \multirow[t]{2}{*}{ Variables } & \multicolumn{2}{|c|}{ ASD effect } & \multicolumn{2}{|c|}{ Light effect } & \multicolumn{2}{|c|}{$\begin{array}{c}\text { ASD } \times \text { light } \\
\text { effect }\end{array}$} \\
\hline & $F$ & $P$ & $F$ & $P$ & $F$ & $P$ \\
\hline \multicolumn{7}{|l|}{ Morphological traits } \\
\hline Height $(\mathrm{cm})$ & 198.48 & $* * * *$ & 47.27 & $* * * *$ & 0.52 & ns \\
\hline Diameter $(\mathrm{mm})$ & 149.27 & $* * * *$ & 11.69 & $* *$ & 1.33 & ns \\
\hline Heigth/diameter & 4.85 & $*$ & 43.37 & $* * *$ & 1.64 & ns \\
\hline Number of nodes/GU ${ }^{2}$ & 60.72 & $* * * *$ & 0.04 & $\mathrm{~ns}$ & 2.86 & $\mathrm{~ns}$ \\
\hline Internode length $(\mathrm{mm})$ & 74.30 & $* * * *$ & 3.96 & $\mathrm{~ns}$ & 3.40 & ns \\
\hline Leaf thickness $(\mu \mathrm{m})$ & 43.95 & $* * * *$ & 23.31 & $* * * *$ & 1.33 & ns \\
\hline Stomatal density $\left(\mathrm{n} \mathrm{mm}^{-2}\right)$ & 103.53 & $* * * *$ & 61.14 & $* * * *$ & 1.17 & ns \\
\hline LMA $\left(\mathrm{g} \mathrm{m}^{-2}\right)^{3}$ & 32.64 & $* * * *$ & 83.62 & $* * * *$ & 0.26 & ns \\
\hline \multicolumn{7}{|l|}{ Anatomical traits } \\
\hline Leaf density $\left(\mathrm{g} \mathrm{cm}^{-3}\right)$ & 1.63 & ns & 61.61 & $* * * *$ & 0.53 & ns \\
\hline Palisade mesophyll $1^{4}$ & 5.88 & $*$ & 52.15 & $* * * *$ & 1.14 & $\mathrm{~ns}$ \\
\hline Spongy mesophyll ${ }^{4}$ & 0.04 & ns & 2.29 & ns & 1.42 & ns \\
\hline Free air space ${ }^{4}$ & 0.50 & ns & 12.41 & $* *$ & 0.74 & $\mathrm{~ns}$ \\
\hline Lower epidermis $^{4}$ & 19.92 & $* * * *$ & 0.12 & ns & 0.38 & ns \\
\hline Upper epidermis 4 & 0.76 & ns & 0.24 & ns & 1.12 & ns \\
\hline \multicolumn{7}{|l|}{ Functional traits } \\
\hline$A_{\operatorname{maxm}}\left(\mathrm{nmol} \mathrm{CO} \mathrm{Co}_{2} \mathrm{~g}^{-1} \mathrm{~s}^{-1}\right)^{5}$ & 6.69 & $* *$ & 104.33 & $* * * *$ & 0.85 & ns \\
\hline$A_{\operatorname{maxa}}\left(\mu \mathrm{mol} \mathrm{CO} \mathrm{Cm}^{-2} \mathrm{~s}^{-1}\right)^{6}$ & 116.32 & $* * * *$ & 1.29 & ns & 2.69 & $*$ \\
\hline$N_{\mathrm{m}}\left(\mathrm{mg} \mathrm{g}^{-1}\right)^{7}$ & 73.42 & $* * * *$ & 165.43 & $* * * *$ & 10.99 & $* *$ \\
\hline$N_{\mathrm{a}}\left(\mathrm{g} \mathrm{m}^{-2}\right)^{8}$ & 84.74 & $* * * *$ & 30.46 & $* * * *$ & 0.61 & ns \\
\hline
\end{tabular}

${ }^{1}$ For the description of the ASD, see Materials and methods. ${ }^{2}$ Growth Unit. ${ }^{3}$ Leaf mass per unit leaf area. ${ }^{4}$ Volumetric leaf fraction. ${ }^{5}$ Lightsaturated rate of photosynthesis per unit leaf dry mass. ${ }^{6}$ Light-saturated rate of photosynthesis per unit leaf area. ${ }^{7}$ Nitrogen content per unit leaf dry mass. ${ }^{8}$ Nitrogen content per unit leaf area.

Simple linear and stepwise multiple linear regressions between the morphological, anatomical and functional leaf variables were calculated using STATISTICA (Kernel v. 5.5 StatSoft INC, USA). The normality of the data and the homogeneity of the variances were examined by Lilliefors and Lewene tests and $\log _{10}$ transformations were occasionally applied to normalise the distributions of the data and/or residuals. Because the independent variables could be correlated, multiple regression models were also subjected to collinearity diagnostics by calculating the variance inflation coefficients and the tolerance indices $[11,48]$. The $D$-statistic was also calculated to check for possible autocorrelation errors [22]. All statistical relationships were considered significant at $p<0.01$.

\section{RESULTS}

\subsection{Effects of light availability and ASD on whole plant and leaf morphology and anatomy}

Most morphological traits were strongly affected by ASD and light availability (Tab. II). ASD resulted as expected in dif-

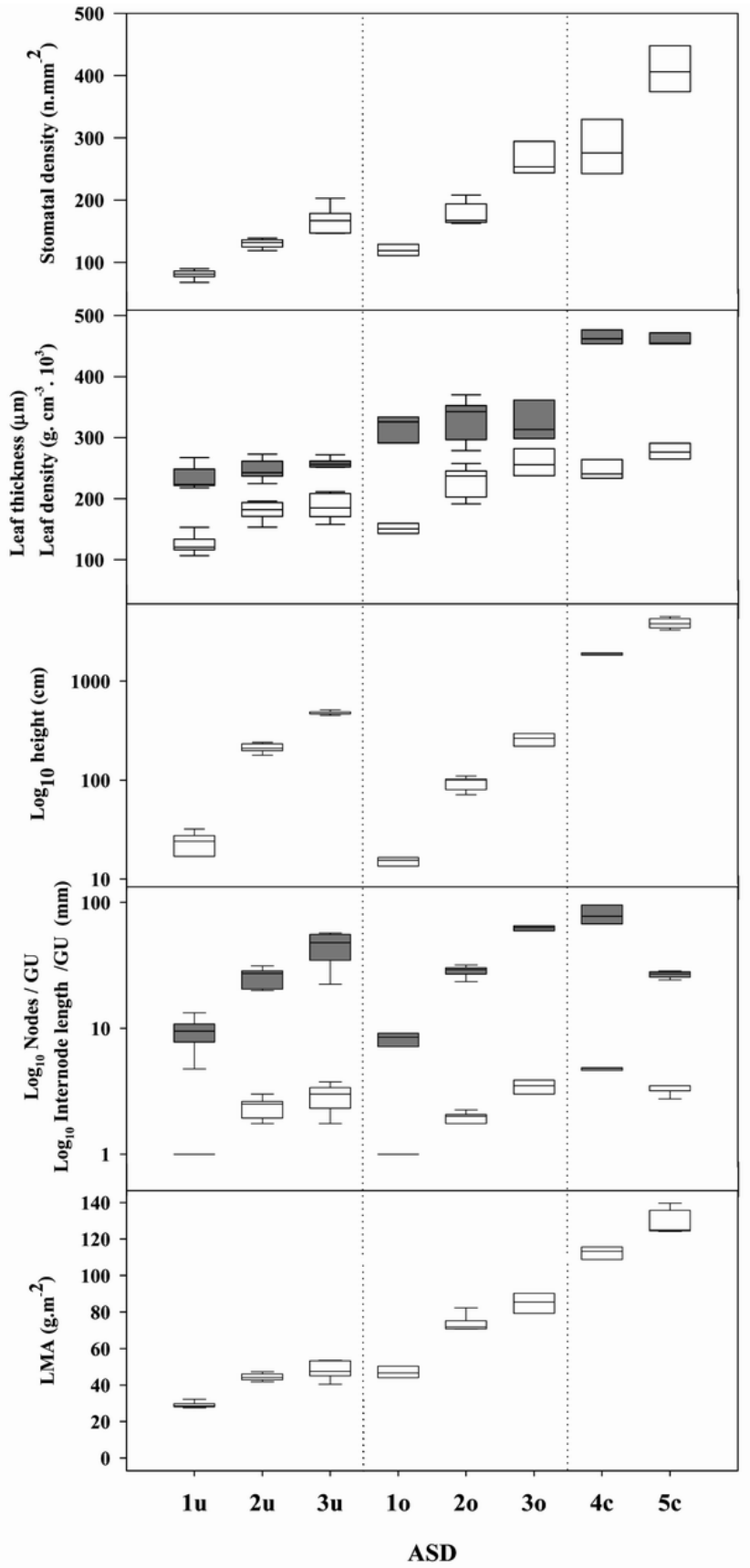

Figure 2. Box plots of stomatal density, leaf density (gray box) and thickness (white box), tree height, internode length per growth unit (gray box), number of nodes per growth unit (white box) and leaf mass to area ratio (LMA) for Dicorynia guianensis at different stages of development (ASD 1, 2, 3, 4 and 5) and in three contrasting light environments ( $\mathrm{u}$ : forest understorey; o: open area and c: forest canopy) (abbreviations as in Tab. II). The upper and lower border of the boxes are the 75th and 25th percentiles, respectively, the black horizontal lines within the boxes are medians and the error bars are the 10th and 90th percentiles. For a complete description of the ASD, see Materials and methods.

ferences in tree height and diameter. Height increased with ASDs but decreased with increasing irradiance (Fig. 2): at any $\mathrm{ASD}$, trees in the clearing were generally smaller than those in 


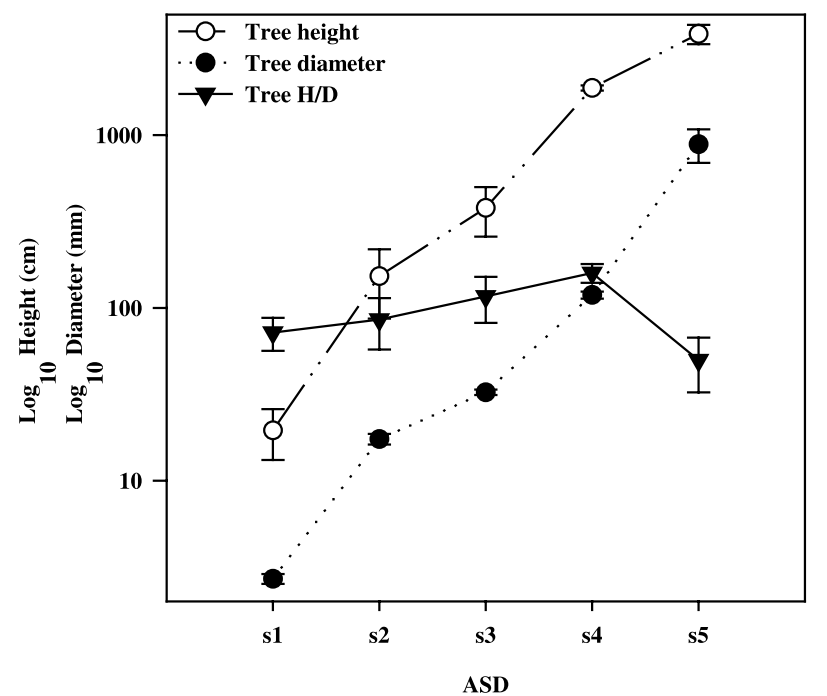

Figure 3. Effects of the architectural stage of development (ASD, s1, $2,3,4,5)$ on tree height, tree diameter and tree height/diameter ratio in Dicorynia guianensis. Means $( \pm \mathrm{SD})$ are given. Mean values were calculated from individuals at low and medium light for $\mathrm{s} 1(n=10)$, s2 $(n=10)$ and s3 $(n=10)$; and from individuals at high light for s4 $(n=5)$ and s5 $(n=5)$. For details on light environments, see Table I.

the understorey. The height/stem diameter ratio (H/D) was weakly affected by ASD (Tab. II): tree height and diameter increased gradually from one ASD to the next one so that H/D remained constant (Fig. 3). This ratio then decreased at ASD 5.

Across all ASDs, there was approximately a three-fold increase in leaf thickness, a five-fold increase in stomatal density and a 4.5-fold increase in LMA (Fig. 2). In general, the range of variation was larger for ASDs in the clearing than in the understorey, particularly for LMA and stomatal density. LMA was lower at low than at medium irradiance; the lower values being associated with lower values of leaf thickness and stomatal density. ASD 4 and 5 displayed the highest values of LMA and stomatal density but their leaf thickness was not significantly different from that of ASD 2 and 3 at medium light.

Number of nodes and internode length per growth unit increased significantly from ASD1 to 4 under low and medium irradiance, and then decreased for ASD 5 (Fig. 2). Across all ASDs, the means ranged from 1 to $4.75 \pm 0.2$ (SD) nodes per growth unit and from $8.12 \pm 1.5$ to $80 \pm 18.3 \mathrm{~mm}$ for internode length. No difference was found between similar ASDs in the understorey and the clearing, nor between ASD 5 and ASD 3 at low and medium light (mean number of nodes $=3.31 \pm 0.32$ and mean internode length $=26.68 \pm 1.7 \mathrm{~mm}$ ). These two parameters were controlled mainly by ASD and not by irradiance.

Little variation was detected in the leaf fractional composition in relation to ASD (Tab. II), which scaled in direct proportion with leaf thickness (data not shown). On the contrary, irradiance modulated the different tissues independently (Tab. II and Fig. 4); with increasing irradiance, the contribution of palisade mesophyll, increased (10 to $25 \%$ ) and that of free air spaces (FAS) decreased (45 to $31 \%$ ). Leaf density increased with irradiance (mean variation within datasets was two-folds;

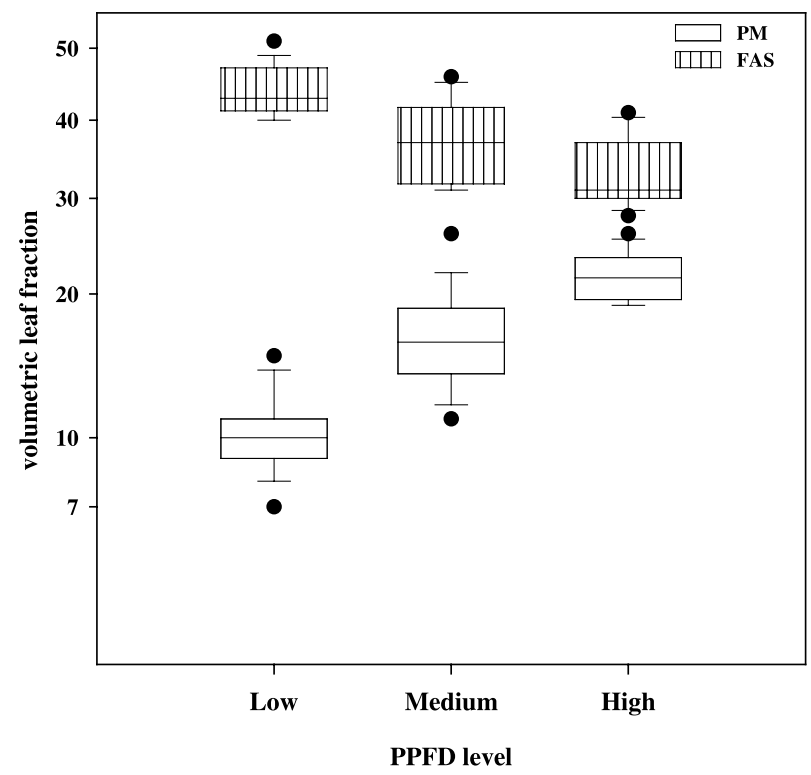

Figure 4. Box plots showing the effects of light availability (low, forest understorey; medium, clearing and high, forest canopy) on leaf anatomy in Dicorynia guianensis (values expressed in volumetric leaf fraction). For details on light environments, see Table I. PM, palisade mesophyll; FAS, free air space.

Fig. 2), but remained similar among ASDs at any given irradiance. The highest value found in canopy trees was about $0.47 \mathrm{~g} \mathrm{~cm}^{-3}$.

\subsection{Leaf functions}

Most functional variables were affected by both ASD and irradiance (Tab. II and Fig. 5). $A_{\text {maxa }}$ increased with ASDs but remained almost not affected by irradiance. $A_{\text {maxm }}$ was few sensitive to ASD but decreased largely with increasing irradiance. Leaf variables displayed the largest range of variation at medium light (Fig. 5). The ASD effect was to increase $N_{\mathrm{a}}$ and $N_{\mathrm{m}}$ in the understorey and clearing. $N_{\mathrm{a}}$ and $N_{\mathrm{m}}$ were maximal at ASD 4 and decreased at ASD 5. The comparisons between ASDs at low and medium light revealed a decrease in $N_{\mathrm{m}}$ with increasing light availability, while $N_{\mathrm{a}}$ increased moderately.

In all cases, the values observed at high irradiance were close to those of ASD 3 at medium light, suggesting that the variables were less sensitive to the effects of the environment above a certain threshold of light intensity. The increase in $N_{\mathrm{a}}$ resulted more from the increase in LMA than in $N_{\mathrm{m}}$ at low light (mean variations were 1.65-fold vs. 1.32-fold, respectively; Fig. 2), while both increased in parallel at medium light (mean variations were 1.79-fold vs. 1.63-fold, Fig. 2). $N_{\mathrm{m}}$ decreased faster than LMA increased at high light (mean variations were 1.3-fold vs. 1.15-fold, respectively; Fig. 2) causing a decrease in $N_{\mathrm{a}}$. Figures 2 and 5 show that, within the two irradiance classes, LMA increased from ASD 1 to ASD 3 with increasing $N_{\mathrm{m}}$, while $A_{\text {maxm }}$ did almost not vary. 


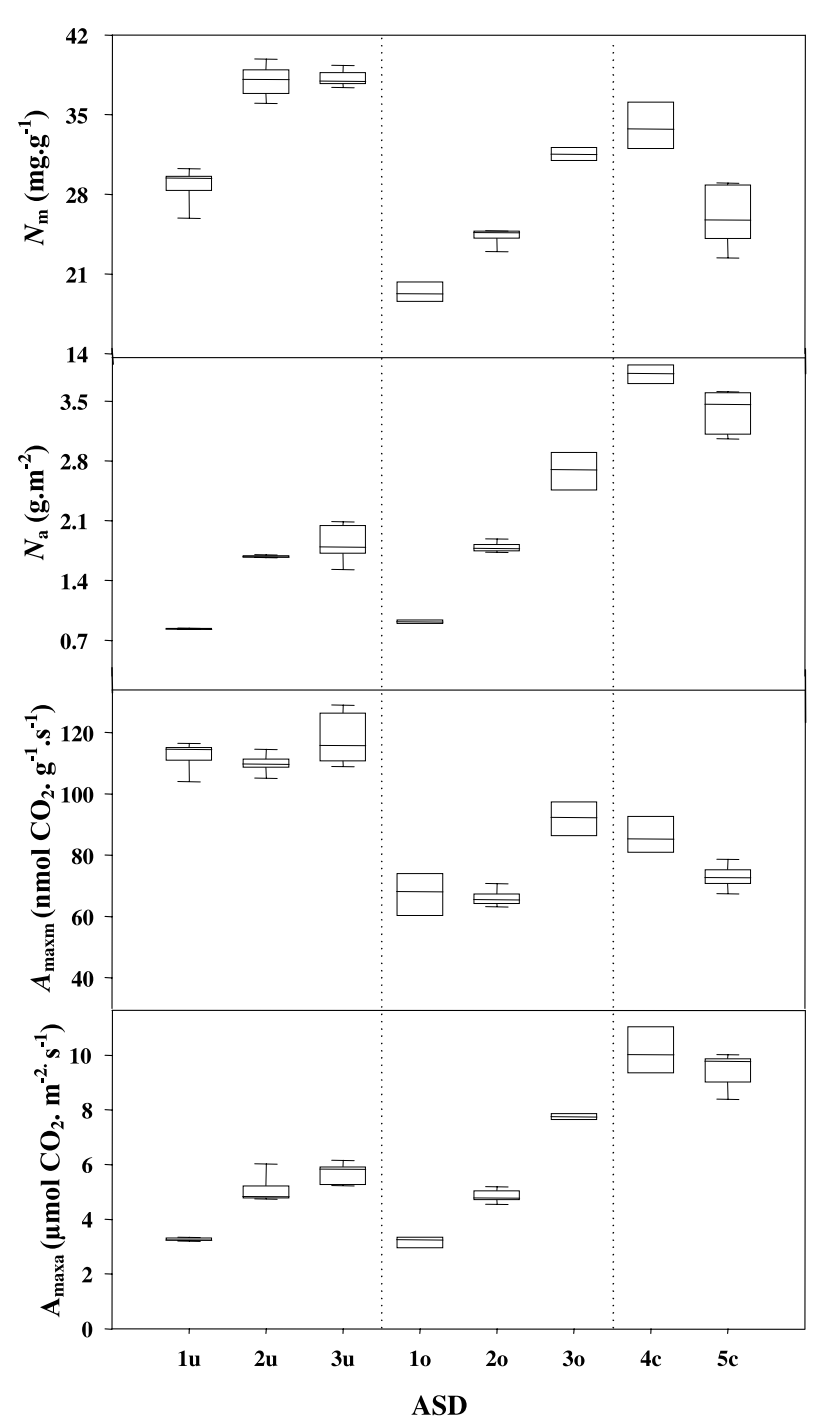

Figure 5. Box plots of mass and area based net $\mathrm{CO}_{2}$ assimilation rates $\left(A_{\max }, A_{\text {maxm }}\right.$, respectively) and mass and area based $\mathrm{N}$ content $\left(N_{\mathrm{m}}\right.$ and $N_{\mathrm{a}}$, respectively) in Dicorynia guianensis at different stages of development (ASD 1, 2, 3, 4 and 5) and in three contrasting light environments (u: forest understorey; o: open area and c: forest canopy) (abbreviations as in Table II). For a complete description of the ASD, see Materials and methods.

\subsection{Bivariate and multivariate relationships between morphological, anatomical and functional leaf traits}

The correlations were first examined within each irradiance class, then across ASDs in the low and medium light classes.

\subsubsection{Correlations between morphological and anatomical leaf traits}

ASD modulated LMA through leaf thickness (T) but not leaf density (D): LMA was strongly and positively related to T within each light class $\left(R^{2}\right.$ values of $0.87,0.88$ and 0.90 at low, medium and high light, respectively; Tab. III). For the pooled data, LMA was modulated by both T and D: both variables were
Table III. Linear (Pearson product moment) correlations between LMA $\left(\mathrm{g} \mathrm{m}^{-2}\right)$ and leaf density $\left(\mathrm{g} \mathrm{cm}^{-3}\right)$ and thickness $(\mu \mathrm{m})$ in Dicorynia guianensis at different stages of development and along a gradient of light availability. Overall correlations are based on data pooled at low and medium light. Levels of significance $(P)$ are given. Significant levels: ns; $p>0.05 ; * p<0.05 ; * * p<0.01$; *** $p<0.001$; $* * * * p<0.0001$.

\begin{tabular}{lcccc}
\hline \multirow{2}{*}{ Leaf attributes } & \multicolumn{3}{c}{ Light availability } & \multirow{2}{*}{ Overall } \\
\cline { 2 - 4 } & Low & Medium $^{2}$ & High $^{3}$ & \\
\hline Density & $0.39^{\text {ns }}$ & $0.20^{\text {ns }}$ & $0.37^{\text {ns }}$ & $0.96 * * * *$ \\
Thickness & $0.94 * * * *$ & $0.94 * * * *$ & $0.96 * * * *$ & $0.97 * * * *$ \\
\hline
\end{tabular}

1 Architectural stages of development (ASD 1, 2 and $3, n=15$ ) in the forest understorey. ${ }^{2}$ Architectural stages of development (ASD 1, 2 and $3, n=15$ ) in clearing. ${ }^{3}$ Architectural stages of development (ASD 4 and $5, n=10$ ) in the forest canopy. For the description of the ASD, see Materials and methods.

Table IV. Relationships of palisade mesophyll and free air space volumetric leaf fractions with leaf thickness $(\mu \mathrm{m})$ and leaf density $\left(\mathrm{g} \mathrm{cm}^{-3}\right)$ in leaves of Dicorynia guianensis grown in understorey and in clearing (results of multiple linear regression analyses ${ }^{1}$ ).

\begin{tabular}{|c|c|c|c|c|c|c|c|c|}
\hline \multirow{3}{*}{$\begin{array}{l}\text { Dependent } \\
\text { variable }\end{array}$} & \multirow[b]{3}{*}{ Intercept } & \multirow[b]{3}{*}{$p$} & \multicolumn{4}{|c|}{ Independent variable } & \multirow[b]{3}{*}{$r^{2}$} & \multirow[b]{3}{*}{$n$} \\
\hline & & & \multicolumn{2}{|c|}{ PM } & \multicolumn{2}{|c|}{ FAS } & & \\
\hline & & & Slope & $p$ & Slope & $p$ & & \\
\hline Thickness & -427.9 & 0.0001 & 0.65 & 0.0001 & 0.38 & 0.0001 & 0.90 & 30 \\
\hline $\log _{10}$ density & 0.48 & 0.0002 & 0.63 & 0.0001 & -0.47 & 0.01 & 0.40 & 30 \\
\hline
\end{tabular}

1 Stepwise regression procedures were used in all cases. Independent variables used in the initial regression model were: palisade mesophyll (PM), spongy mesophyll (SM), free air space (FAS), lower epidermis (LE) and upper epidermis (UE) volumetric leaf fractions. All statistical relationships were considered significant at $p<0.01$.

strongly and positively related to LMA (according to the multiple regression model, the slope between LMA and T was similar to those found in each environment, data not shown). The independent variables were weakly correlated (variance inflation factor $(\mathrm{VIF})<10$, tolerance indice $=0.62$ ).

Across the pooled set of data, variations of T and density D were explained by free air space and palisade mesophyll (PM) (Tab. IV). The independent variables were poorly correlated $\left(R^{2}=0.30 ; p<0.001\right)$. The slopes of the density vs. PM and thickness vs. PM relationships were similar, with a strong and positive correlation, T was also positively related to FAS, while $\mathrm{D}$ negatively. For these relationships the explained variances were lower for $\mathrm{D}$ than for $\mathrm{T}$.

\subsubsection{Covariations in the light-saturated rates of photosynthesis ( $A_{\text {maxa }}$ and $A_{\text {maxm }}$ ), leaf thickness and density}

The correlations between $A_{\operatorname{maxm}}, A_{\text {maxa }}$ and leaf density and thickness are presented in Table V. $A_{\text {maxa }}$ was strongly and positively related to leaf thickness but not to density, while $A_{\text {maxm }}$ 
Table V. Linear (Pearson product moment) correlations between area-based and mass-based light-saturated net $\mathrm{CO}_{2}$ assimilation rates and leaf density $\left(\mathrm{g} \mathrm{cm}^{-3}\right)$ and thickness $(\mu \mathrm{m})$ in Dicorynia guianensis at different stages of development and along a gradient of light availability. Overall correlations are based on data pooled at low and medium light. Levels of significance $(p)$ are given. Significant levels: ns; $p>0.05 ; * p<0.05$; $* * p<0.01 ; * * * p<0.001 ; * * * * p<0.0001$ (results of multiple linear regression analyses).

\begin{tabular}{|c|c|c|c|c|c|c|c|c|}
\hline \multirow{3}{*}{ Leaf attributes } & \multicolumn{6}{|c|}{ Light availability } & & \\
\hline & \multicolumn{2}{|c|}{ Low 1} & \multicolumn{2}{|c|}{ Medium $^{2}$} & \multicolumn{2}{|c|}{$\mathrm{High}^{3}$} & \multicolumn{2}{|c|}{ Overall } \\
\hline & $A_{\operatorname{maxa}}$ & $A_{\operatorname{maxm}}$ & $A_{\operatorname{maxa}}$ & $A_{\operatorname{maxm}}$ & $A_{\operatorname{maxa}}$ & $A_{\operatorname{maxm}}$ & $A_{\operatorname{maxa}}$ & $A_{\operatorname{maxm}}$ \\
\hline Density & $0.26^{\mathrm{ns}}$ & $-0.16^{\mathrm{ns}}$ & $0.21^{\mathrm{ns}}$ & $-0.20^{\mathrm{ns}}$ & $-0.28^{\mathrm{ns}}$ & $-0.48^{\mathrm{ns}}$ & $-0.07^{\mathrm{ns}}$ & $-0.79 * * * *$ \\
\hline Thickness & $0.89 * * * *$ & $-0.21^{\mathrm{ns}}$ & $0.88 * * * *$ & $0.47^{\mathrm{ns}}$ & $-0.50^{\mathrm{ns}}$ & $-0.72^{\mathrm{ns}}$ & $0.75 * * * *$ & $-0.006^{\mathrm{ns}}$ \\
\hline
\end{tabular}

${ }^{1}$ Architectural stages of development (ASD 1, 2 and 3,n=15) in the forest understorey. ${ }^{2}$ Architectural stages of development (ASD 1, 2 and 3 , $n=15$ ) in clearing. ${ }^{3}$ Architectural stages of development (ASD 4 and $5, n=10$ ) in the forest canopy. For the description of the ASD, see Materials and methods.

was independent of both variables. Such relationships were not found at high light, since both $A_{\operatorname{maxa}}$ and $A_{\text {maxm }}$ were independent of T and D. Across the pooled set of data, $A_{\text {maxa }}$ showed a strong correlation with $\mathrm{T}\left(R^{2}=0.63, p<0.0001\right)$ but not with D. $A_{\text {maxm }}$ was strongly and negatively related to $\mathrm{D}\left(R^{2}=0.62\right.$, $p<0.0001$ ) but not to T. T and D were autocorrelated but the fit was poor (tolerance indice of 0.63 in the relationship with $A_{\text {maxm }}$ and of 0.74 with $A_{\text {maxa }}$ ).

\section{DISCUSSION}

\subsection{Influence of ASD and irradiance on tree dimensions}

The number of nodes and the internode length per GU increased significantly in understorey and clearing trees, until a threshold value corresponding to the onset of branching (i.e. ASD 3). The observed values were independent of irradiance suggesting that these GU traits are species-specific and nonresponsive to changes in light conditions. The number of nodes and the internode length per GU are recognised as relevant indicators of the meristem productivity or "plant vigour" [9, 40,49 , 53]. Thus, each ASD displays a precise meristem productivity corresponding to a "vigour threshold" that the plant must step over to reach the following stage (i.e. from a stage with simple leaves to a stage with compound leaves, from a non-branching to a branching stage, from a non-reiterated to a reiterated stage, ...) and go trough the "installation phase" [9, 19, 36, 49, 51, 71] also called "rising phase" [88]. The comparison of trees at similar height revealed that the meristem productivity was higher in the clearing (e.g. ASD 3), in producing longer internodes and more nodes per GU, than in the understorey (e.g. ASD 2). The former had already reached the threshold value allowing branching, while the latter in the understorey were expected to reach it later and at a larger height. It is likely that the trees growing in the clearing displayed a shorter phase of installation than the trees in the understorey. This further indicates that light conditions did not qualitatively modify the developmental sequence of the species but modulated its progress by accelerating or slowing it down, as the ecological conditions were favourable or limiting. According to the environmental conditions, a development stage can thus be reached for different global dimensions like total height, as demonstrated by Sabatier and
Barthélémy [78] on Cedrus atlantica, Nicolini et al. [50] and Heuret et al. [36] on Quercus petraea. As suggested by these authors, one can reasonably presume that, (i) for a given ASD (i.e., trees with similar physiological ages), trees in the clearing were chronologically younger than those in the understorey, (ii) there was a difference in both the physiological and chronological ages between trees of similar height and growing in these two environments (see also [9] for review). This raises questions on the reliability of a height-based sampling strategy for evaluating the phenotypic plasticity of trees in relation to light conditions. The variations which can be observed in some traits could be only related to differences in the physiological ages between trees.

Both components of the H/D ratio were influenced by the ecological conditions in which the trees were growing. Since tree height decreased with increasing light availability whereas the diameter was little affected, the H/D was lower at medium than at low light. This indicates that the species displays a high morphological plasticity in response to light variations; in particular by growing in height rather than in diameter when competition for light is high, as observed by Sterck and Bongers [82] in the same species. Such a growth strategy in the understorey is rather observed for trees of the shade-intolerant species [2].

The sequence of differentiation in D. guianensis previously defined by Drénou [20], consists in two main periods with regard to the quantitative changes we observed: a phase (from the ASD 1 to the ASD 4), with a concomitant growth in height and diameter (constant H/D), and during which trees build a trunk constituted by longer successive GUs, with gradually more nodes and longer internodes. This phase stops when the plant experiences the reiteration process [64] which causes the tree crown formation and the first expression of sexuality. The second phase is related to the expansion of the mature crown by the occurrence of numerous reiterated complexes (ASD 5, [20]), whereas the tree H/D decreases (investments in favour of growth in thickness rather than in height). This phase ends with the ageing of the reiterated complexes, which is marked by their progressive structural reduction and characterized here by the decrease in the number of nodes and in the internode length per GU. Such phenomenon has been observed in numerous tree species $[14,20,29,40,41]$ and corresponds to the falling phase [88]. 


\subsection{Leaf morphology and anatomy}

Classical patterns of response of leaves to changing light conditions were observed between trees at low and medium irradiance $[1,12,21,26,39,46,57,58,61,63,66,67,74,86$, 90]. Leaf thickness and density, leaf dry mass per area and stomatal density increased with increasing irradiance pointing out the large leaf plasticity of the species. The increase in stomatal density may be related to the increase in light, promoting higher carbon gains, or to the increase in temperature and drought, maximising transpiration rates and evaporative cooling as suggested by $[1,17,42,46]$. Increases in LMA observed here may enable the concentration of photosynthetic compounds per unit area (see [32]) and enhance the resistance to water limitation in leaves with higher cell packing, as suggested by Givnish [30]. This is supported by the fact that LMA scaled in direct proportion with leaf density and thickness, and that density correlated strongly and positively with PM and negatively with FAS. This resulted in a higher fraction of PM and a lower fraction of free air spaces at high light, as shown by Lee et al. [46] in the Dipterocarpaceae species. Such anatomical adjustments have important repercussions at the functional level. The increase in the leaf free air space under low light conditions may result in improved $\mathrm{CO}_{2}$ diffusion to the carboxylation sites and enhanced light absorptance by scattering radiations (Poorter et al. [69]). The increase in the fraction of palisade mesophyll by lengthening the cell size at high light (data not shown) may enhance the gas exchange surfaces, which may counterbalance the increased diffusive resistance of $\mathrm{CO}_{2}$ due to the decrease in the free air spaces $[61,85]$. These adjustments probably play a key role in the foliar anatomical plasticity of D. guianensis since the free air spaces represent up to $45 \%$ of the leaf tissue at low light.

Variations in LMA, stomatal density and leaf thickness were also observed within light classes and among ASDs. Changes in LMA were caused by changes in leaf thickness but not in density. Increases in LMA with increasing tree age or size are well documented [26, 56, 60, 74, 89]. Variations in LMA related to changes in leaf thickness have been also reported in numerous species [58]. It is likely that the increase in leaf thickness in the understorey results from the light acclimation process to low irradiance. D. guianensis, like numerous other tropical species $[67,86]$, increases its leaf life-span in the understorey (mean leaf life span of saplings in understorey ranging from 3 to 4 years $[5,74]$ vs. 18 months in clearings [5]. This results in a greater biomass accumulation and provides a means to compensate for the leaf construction costs over time [6, 73, 83], and to enable the construction of an efficient foliar display for light interception [30, 68, 87]. Because leaf size also increases with increasing tree age in D. guianenis (data not shown) such adjustments require an increasing assimilate investment in the leaf area formation during tree development. Since the leaf thickness is positively related to additional photosynthetically competent mesophyll layers, its increase with increasing tree age in the understorey could be the mechanism by which D. guianensis maintains a high leaf life-span during its development [62]. Conversely, the species could acclimate to high irradiance by investing more in carboxylating enzymes and proteins responsible for the photosynthetic electron transport. Since leaf size also increases with increasing tree age in the clearing (data not shown), there is undoubtedly a need for D. guianensis to concentrate photosynthesising weight per unit leaf area for optimising photosynthesis as it develops.

The effects of irradiance on most of the morphological leaf traits are supplemented by variations brought about by the developmental stages of the trees. This was however not observed at the anatomical level. The changes observed in response to tree ASD suggest that some leaf traits could have an ASD-dependence. This hypothesis contradicts the views of Harper [35] and Sachs et al. [79] who considered leaves as populations of relatively independent organs. More investigations are however needed to test the validity of this assumption.

\subsection{Leaf function}

Although light-related changes displayed large ranges of variation in this study, most of the functional parameters were also severely affected by ASD. Comparisons between ASDs at low and medium light indicated a decrease in $N_{\mathrm{m}}$ and $A_{\text {maxm }}$ with increasing light availability, while $N_{\mathrm{a}}$ increased and $A_{\text {maxa }}$ remained unaffected. Such patterns of foliage functional activity across natural light gradients are tightly linked to the species potential to endure shade, as demonstrated in Picea abies [56], Corylus avellana and Lonicera xyslosteum [43]. Generally, shade tolerant species invest proportionally more nitrogen in compounds responsible for light capture, but this strategy requires much nitrogen at the leaf level [54]. As a result, $N_{\mathrm{m}}$ may increase with decreasing light availability. Our data allow assessment of the relative importance of changes in LMA and $N_{\mathrm{m}}$ for the leaf photosynthetic light acclimation in D. guianensis. Changes observed with increasing irradiance were not similar to changes reported for peach by Rosati et al. [77]. These authors found that changes in LMA were more important than changes in nitrogen for leaf light acclimation. The control of photosynthetic light acclimation by LMA has been observed for many tree species (Le Roux et al. [44, 45] and for several shade-tolerant herbaceous species [80]. Comparison of these different results shows that there is no universal rule concerning the relative importance of the factors controlling the light acclimation of photosynthetic capacities. The rates of light-saturated photosynthesis $A_{\text {maxa }}$ were rather low, but generally in the same range as those measured in other tropical rainforest seedlings and plants $[18,23,38,47,72]$. A positive scaling of $A_{\operatorname{maxa}}$ with leaf thickness was observed, which is compatible with the positive scaling of thickness vs. PM we observed on the pooled set of data. However, the lack of significant variation in $A_{\max a}$ with light availability suggests that this scaling reflects variations in thickness due to the ASD effect in both light classes, and which result in accumulating photosynthetically competent mesophyll layers per unit leaf area with increasing T. This suggests that $D$. guianensis displays a low functional plasticity in response to light variations, thus confirming its shade-tolerant status. Our conclusions are inconsistent with those of Rijkers et al. [75], who found a great plasticity in the photosynthesis rates in this species, with respect to its growth light conditions (height-based sampling). These opposite conclusions highlight the importance of using an architectural approach in the sampling strategy when functional responses of plants are studied in contrasting environments. 
The significant decrease in $A_{\text {maxm }}$ with increased light availability suggests that anatomical adjustments have a diluting effect on the leaf compounds responsible for $\mathrm{CO}_{2}$ assimilation [27]. It is likely that an increase in PM thickness due to a lengthening of the cell size with increasing relative irradiance may result in decreasing chloroplast density, which, in turn, may cause a decline in the photosynthetic capacity per unit foliar weight, as demonstrated for Piper arieianum [17].

Conversely, as a result of the ASD effect, $N_{\mathrm{a}}, N_{\mathrm{m}}$ and $A_{\text {maxa }}$ increased, while $A_{\text {maxm }}$ was globally unaffected. The increase in $N_{\mathrm{a}}$ was compatible with that of LMA, due to the ASD effect we observed in both light classes. LMA scales strongly and positively with leaf thickness and T with the mesophyll tissue. This could result in accumulating photosynthetic proteins per unit leaf area, thus enhancing the rates of photosynthesis per unit area. This is also supported by the positive scaling found between $A_{\text {maxa }}$ and leaf thickness at both low and medium light and by the increase in $N_{\mathrm{m}}$ with respect to the ASD. The LMA gave with $N_{\mathrm{m}}$ a multiple hyperbolic relationship over all irradiances and tree ASD (data not shown). Such pattern is the result of the negative and positive scaling of LMA with $N_{\mathrm{m}}$ with respect to the irradiance and tree ASD, respectively. This suggests that the mechanisms underlying the relationship of the leaf structure $v s$ irradiance and $v s$ tree ASD may act on $N_{\mathrm{m}}$ in a different way. Therefore, because both the photosynthetic capacities and the leaf tissue volume increased with changing ASD on a leaf area basis, the $A_{\text {maxm }}$ remained fairly constant. Thus, the ASD-related changes in the photosynthetic capacities in D. guianensis result more from an increase in the amount of tissue per unit area, than from changes in the photosynthetic capacity per unit leaf tissue.

\section{CONCLUSIONS}

The study looked at the interactive effects of tree developmental stage and light availability on different plant traits in the tropical species Dicorynia guianensis. Our results underpinned the statement that some traits could have an ASD-dependence at the whole plant and leaf level. In general, functional traits were less influenced by ASD and light effects than the morphological and anatomical traits, as reported by Valladares et al. [86] on sixteen species of a Panamanian rainforest. Also, the variations were larger between light environments than between the ASD. However, although D. guianensis displayed a high morphological and anatomical plasticity in response to light conditions, changes in leaf traits did not coincide with changes in the photosynthetic capacities. Further studies on total nitrogen partitioning among the different pools of the photosynthetic machinery are needed to better elucidate the functional plasticity of D. Guianensis.

Acknowledgements: The authors thank Drs Erwin Dreyer and Daniel Barthélemy for their constructive comments on the manuscript. Financial support was provided by the "CIRAD-INRA 2000 fund".

\section{REFERENCES}

[1] Abrams M.D., Kubiske M.E., Leaf structural characteristics of 31 hardwood and conifer tree species in central Wisconsin: influence of light regime and shade-tolerance rank, For. Ecol. Manage. 31 (1990) 245-253.

[2] Ackerly D.D., Canopy structure and dynamics: integration of growth processes in tropical pioneer trees, in: Mulkey S.S., Chazdon R.L., Smith A.P. (Eds.), Tropical forest plant ecophysiology, Chapman and Hall, New York, 1996, pp. 619-658.

[3] Allsopp A., Heteroblastic development in vascular plants, Adv. Morphog. 6 (1967) 127-171.

[4] Ashby E., Studies in the morphogenesis of leaves, New Phytol. 47 (1948) 153-176.

[5] Baraloto C., Tradeoffs between neotropical tree seedling traits and performance in contrasting environments, Ph.D. dissertation, Philosophy (Ecology and Evolutionary Biology), University of Michigan, 2001.

[6] Barthod S., Epron D., Variation of construction cost associated to leaf area renewal in saplings of two co-occurring temperate tree species (Acer platanoides L. and Fraxinus exelsior L.) along a light gradient, Ann. For. Sci. 62 (2005) 545-551.

[7] Bariteau M., Geoffroy J., Sylviculture et régénération naturelle en forêt guyanaise, Rev. For. Fr. 41(1989) 309-323.

[8] Barthélémy D., Levels of organization and repetition phenomena in seed plants, Acta Biotheor. 39 (1991) 309-323.

[9] Barthélémy D., Botanical background for plant architecture analysis and modelling, in: Bao-Gang Hu, M. Jaeger (Eds.), Plant Growth Modelling an Applications, Bejing (China), October 1316, 2003, Tsinghua University, Springer, 2003, pp. 1-20.

[10] Barthélémy D., Edelin C., Hallé F., Architectural concepts for tropical trees, in: Holm-Nielsen L.B., Nielsen I.C., Balslev H. (Eds.), Tropical forests: botanical dynamics, speciation and diversity, Academic Press, London, 1989, pp. 89-100.

[11] Belsley D.A., Kuhe E., Welsch R.E., Regression diagnostics: identifying influential data and sources of collinearity, John Willey and sons, New York, 1980.

[12] Björkman O., Responses to different quantum flux densities, in: Lange O.L., Nobel P.S., Osmond C.B., Zeigler H. (Eds.), Encyclopedia of Plant Physiology, Springer Verlag, Heidelberg, 1981, pp. 57-107.

[13] Blaise F., Barczi J.F., Jaeger M., Dinouard P., de Reffye P., Simulation of the growth of plants. Modelling of metamorphosis and spatial interactions in the architecture and development of plants, in: Kunii T.L., Luciani A. (Eds.), Cyberworlds, Springer Verlag, Berlin, Tokyo, 1998, pp. 81-109.

[14] Borchert R., The concept of juvenility in woody plants, Acta Hort. 56 (1976) 21-33.

[15] Caraglio Y., Nicolini E., Pétronelli P., Observations on the links between the architecture of a tree (Dicorynia guianensis Amshoff) and Cerambycidae activity in French Guiana, J. Trop. Ecol. 17 (2001) 459-463.

[16] Chabot B.F., Jurik T.W., Chabot J.F., Influence of instantaneous and integrated light-flux density on leaf anatomy and photosynthesis, Am. J. Bot. 66 (1979) 940-945.

[17] Chazdon R.L., Kaufmann S., Plasticity of leaf anatomy of two rain forest shrubs in relation to photosynthetic light acclimation, Funct. Ecol. 7 (1993) 385-394.

[18] Chazdon R.L., Pearcy R.W., Lee D.W., Fetcher N., Photosynthetic responses of tropical forest plants to contrasting light environments, in: Mulkey S.S., Chazdon R.L., Smith A.P. (Eds.), Tropical forest plant ecophysiology, Chapman and Hall, New-York, 1996, pp. 5-55.

[19] Collet C., Colin F., Bernier F., Height growth, shoot elongation and branch development of young Quercus petraea grown under different levels of resource availability, Ann. For. Sci. 54 (1997) 65-81. 
[20] Drénou C., Approche architecturale de la sénescence des arbres. Le cas de quelques angiospermes tempérées et tropicales, $\mathrm{Ph}$.D. dissertation, Université Montpellier II, 1994.

[21] Ducrey M., Variation in leaf morphology and branching pattern of some tropical rain forest species from Guadeloupe (French West Indies) under semi-controlled light conditions, Ann. For. Sci. 49 (1992) 553-570.

[22] Durbin J., Watson G.S., Testing for serial correlations in least squares regression II, Biometrika 38 (951) 159-178.

[23] Eschenbach C., Glauner R., Kleine M., Kappen L., Photosynthesis rates of selected tree species in lowland dipterocarp rain forest of Sabah, Malaysia, Trees 72 (1998) 356-365.

[24] Evans J.R., Partitioning of nitrogen between and within leaves grown under different irradiances, Aust. J. Plant Physiol. 16 (1989) 533-548.

[25] Favrichon V., Classification des espèces arborées en groupes fonctionnels en vue de la réalisation d'un modèle de dynamique de peuplement en forêt guyanaise, Rev. Ecol. Terre Vie 49 (1994) 379403.

[26] Fetcher N., Strain B.R., Oberbauer S.F., Effects of light regime on the growth, leaf morphology, and water relations of seedlings of two species of tropical, Oecologia 58 (1983) 314-319.

[27] Field C., Mooney H.A., The photosynthesis-nitrogen relationship in wild plants, in: Givnish T.J. (Ed.), On the economy of plant form and function, Cambridge University Press, Cambridge, 1986, pp. 25-55.

[28] Friedman M., The use of rank to avoid the assumption of normality implicit in the analysis of variance, J. Am. Stat. Assoc. 32 (1937) 675-701.

[29] Gatsuk L.E, Smirnova O.V., Vorontzova L.I., Zaugolnova L.B., Zhukova L.A., Age states of plants of various growth forms: a review, J. Ecol. 68 (1980) 675-696.

[30] Givnish T.J., Adaptation to sun and shade: a whole plant perspective, Aust. J. Plant Physiol. 15 (1988) 63-92.

[31] Grosfeld J., Barthélémy D., Brion C., Architectural variations of Araucaria araucana (Molina) K. Koch (Araucariaceae) in its natural habitat, in: Kurmann M.H., Hermsley A.R. (Eds.), The Evolution of Plant Architecture, Royal Botanic Gardens, Kew, 1999, pp. 109-122.

[32] Gutschick V.P., Wiegel F.W., Optimizing the canopy photosynthetic rate by patterns of investment in specific leaf mass, Am. Nat. 132 (1988) 67-86.

[33] Hallé F., Oldeman R.A.A., Tomlinson P.B., Tropical trees and forests, Springer-Verlag, Berlin, 1978.

[34] Hanson P.J., Mc Roberts R.E., Isebrands J.G., Dixon R.K., An optimal sampling strategy for determining $\mathrm{CO}_{2}$ exchange rate as a function of photosynthetic photon flux density, Photosynthetica 21 (1987) 98-101.

[35] Harper J.L., The value of a leaf, Oecologia 80 (1989) 53-58.

[36] Heuret P., Barthélémy D., Nicolini E., Atger C., Analyse des composantes de la croissance en hauteur et de la formation du tronc chez le chêne sessile (Quercus petraea (Matt.) Liebl. (Fagaceae) en sylviculture dynamique, Can. J. Bot. 78 (2000) 361-373.

[37] Hoflacher H., Bauer H., Light acclimation in leaves of the juvenile and adult life phase of ivy (Hedera helix), Physiol. Plant. 56 (1982) $117-182$.

[38] Huc R., Ferhi A., Guehl J.M., Pioneer and late stage tropical rainforest tree species (French Guiana) growing under common conditions differ in leaf gas exchange regulation, carbon isotope discrimination and leaf water potential, Oecologia 99 (1984) 297-305.
[39] Kincaid D.T., Anderson P.J., Mori S.A., Leaf variation in a tree of Pourouma tomentosa (Cecropiaceae) in French Guiana, Brittonia 50 (1998) 324-338.

[40] Kozlowsky T.T., Growth and development in trees, Academic Press Inc., New-York, London, 1971.

[41] Krammer P.J., Kozlowsky T.T., Physiology of woody plants, Academic Press Inc., New-York, London, 1979.

[42] Kubiske M.E., Abrams M.D., Mostoller S.A., Stomatal and nonstomatal limitations of photosynthesis in relation to the drought and shade tolerance of tree species in open and understory environments, Trees 11 (1996) 76-82.

[43] Kull O., Niinemets Ü., Variation in leaf morphometry and nitrogen concentration in Betula pendula Roth., Corylus avellana L. and Lonicera xylosteum L., Tree Physiol. 12 (1993) 311-318.

[44] Le Roux X., Grand S., Dreyer E., Daudet F.A., Parameterization and testing of a biochemically based photosynthesis model for walnut (Juglans regia) trees and seedlings, Tree Physiol. 19 (1999) 481-492.

[45] Le Roux X., Sinoquet H., Vandame M., Spatial distribution of leaf dry weight per area and leaf nitrogen concentration in relation to local radiation regime within an isolated tree crown, Tree Physiol. 19 (1999) 181-188.

[46] Lee D., Oberbauer W.S.F., Jonhson P., Krishnapilay B., Mansor M., Mohamad H., Yap S.K., Effect of irradiance and spectral quality on leaf structure and function in seedlings of two southeast Asian Hopea (Dipterocarpaceae) species, Am. J. Bot. 87 (2000) 447-455.

[47] Loik M.E., Holl K.D., Photosynthetic responses of tree seedlings in grass and under shrubs in early-successional tropical old fields, Costa Rica, Oecologia 127 (2001) 40-50.

[48] Neter J., Wasserman W., Kutner H.H., Applied linear statistical models: regression, analysis of variance and experimental designs, Homewood, Illinois, Irwin, 1985.

[49] Nicolini E., Architecture et gradients morphogénétiques chez de jeunes hêtres (Fagus sylvatica L., Fagaceae) en milieu forestier, Can. J. Bot. 76 (1998) 1232-1244.

[50] Nicolini E., Barthélémy D., Heuret P., Influence de la densité du couvert forestier sur le développement architectural de jeunes chênes sessiles, Quercus petraea (Matt.) Liebl. (Fagaceae), en régénération forestière, Can. J. Bot. 78 (2000) 1531-1544.

[51] Nicolini E., Caraglio Y., L'influence de divers caractères architecturaux sur l'apparition de la fourche chez Fagus sylvatica L., en fonction de l'absence ou de la présence d'un couvert, Can. J. Bot. 72 (1994) 1723-1734.

[52] Nicolini E., Chanson B., La pousse courte, un indicateur du degré de maturation chez le hêtre (Fagus sylvatica L.), Can. J. Bot. 77 (1999) 1539-1550.

[53] Nicolini E., Caraglio Y., Pélissier R., Leroy C., Roggy J.C., Epicormic branches: a growth indicator for the tropical forest tree Dicorynia guianensis Amshoff (Caesalpiniaceae), Ann. Bot. 92 (2003) $97-105$.

[54] Niinemets Ü., Distribution of foliar carbon and nitrogen across the canopy of Fagus sylvatica: adaptation to a vertical light gradient, Acta Oecol. 16 (1995) 525-521.

[55] Niinemets Ü., Role of foliar nitrogen in light harvesting and shade tolerance of four temperate deciduous woody species, Funct. Ecol. $11,(1997) 518-531$.

[56] Niinemets Ü., Distribution patterns of foliar carbon and nitrogen as affected by tree dimensions and relative light conditions in the canopy of Picea abies, Trees 11 (1997) 144-154.

[57] Niinemets Ü., Acclimation to low irradiance of Picea abies: influences of past and present light climate on foliage structure and function, Tree Physiol. 17 (1997) 723-732. 
[58] Niinemets Ü., Global-scale climatic controls of leaf dry mass per area, density and thickness in trees and shrubs, Ecology 82 (2001) 453-469.

[59] Niinemets Ü., Kull O., Effects of light availability and tree size on the architecture of assimilative surface in the canopy of Picea abies: variation in needle morphology, Tree Physiol. 15 (1995) 307-315.

[60] Niinemets Ü., Kull O., Biomass investment in leaf lamina versus lamina support in relation to growth irradiance and leaf size in temperate deciduous trees, Tree Physiol. 19 (1999) 349-358.

[61] Niinemets Ü., Kull O., Tenhunent J.D., Variability in leaf morphology and chemical composition as a function of canopy light environment in coexisting deciduous trees, Int. J. Plant Sci. 160 (1999) 837-848.

[62] Nobel P.S., Internal leaf area and cellular $\mathrm{CO}_{2}$ resistance: photosynthetic implications of variations with growth conditions and plant species, Physiol. Plant. 40 (1977) 137-144.

[63] Nobel P.S., Hartsock P.S., Development of leaf thickness for Plecthranthus parviflorus - Influence of photosynthetically active radiation, Physiol. Plant. 51 (1981) 163-166.

[64] Oldeman R.A.A., L'architecture de la forêt guyanaise, Mémoire $\mathrm{n}^{\circ} 73$, Paris: Organisme de Recherche Scientifique pour les Territoires d'Outre-Mer, 1974.

[65] Poethig R.S., Phase change and the regulation of shoot morphogenesis in plants, Science 250 (1990) 923-930.

[66] Ponton S., Dupouey J.L., Dreyer E., Leaf morphology as species indicator in seedlings of Quercus robur L. and Q. petraea (Matt) Liebl.: modulation by irradiance and growth flush, Ann. For. Sci. 61 (2004) 73-80.

[67] Poorter L., Growth responses of fifteen rain forest tree species to a light gradient; the relative importance of morphological and physiological traits, Funct. Ecol. 13 (1999) 396-410.

[68] Poorter L., Werger M.J.A., Light environment, sapling architecture, and leaf display in six rain forest tree species, Am. J. Bot. 86 (1999) 1464-1473.

[69] Poorter L., Kwant R., Hernández R., Medina E., Werger M.J.A., Leaf optical properties in Venezuelan cloud forest trees, Tree Physiol. 20 (2000) 519-526.

[70] Popma J., Bonger S.F., Werger M.J.A., Gap-dependence and leaf characteristics of trees in a tropical lowland rain forest in Mexico, Oikos 63 (1992) 207-214.

[71] Puntieri J., Raffaele E., Martinez P., Barthélémy D., Brion C., Morphological and architectural features of young Nothofagus pumilio (Poepp. et Endl.) Krasser (Fagaceae) plants, Bot. J. Linn. Soc. 130 (1999) 395-410.

[72] Raaimakers D., Boot R.G.A., Dijkstra P., Pot S., Pons T., Photosynthetic rates in relation to leaf phosphorus content in pioneer versus climax tropical rainforest trees, Oecologia 102 (1995) 120-125.

[73] Rijkers T., Leaf function in tropical rain forest canopy trees. The effects of light on leaf morphology and physiology in differentsized trees, Ph.D. dissertation, University of Wageningen, The Netherlands, 2000.
[74] Rijkers T., de Vries J.L., Pons T.L., Bongers F., Photosynthetic induction in saplings of three shade-tolerant tree species: comparing understorey and gap habitats in a French Guiana rain forest, Oecologia 125 (2000) 331-340.

[75] Rijkers T., Pons T.L., Bongers F., The effect of tree height and light availability on photosynthetic leaf traits of four neotropical species differing in shade tolerance, Funct. Ecol. 14 (2000) 77-86.

[76] Rôças G., Barros C.F., Scarano F.R., Leaf anatomy plasticity of Alchornea triplinervia (Euphorbiaceae) under distinct light regimes in a Brazilian montane atlantic rain forest, Trees 11 (1997) 469473.

[77] Rosati A., Esparza G., DeJong T.M., Pearcy R.W., Influence of canopy light environment and nitrogen availability on leaf photosynthetic characteristics and photosynthetic nitrogen-use efficiency of field-grown nectarine trees, Tree Physiol. 19 (1999) 173-180.

[78] Sabatier S., Barthélémy D., Growth dynamics and morphology of annual shoots, according to their architectural position, in young Cedrus atlantica (Endl.) Manetti ex Carrière (Pinaceae), Ann. Bot. 84 (1999) 387-392.

[79] Sachs T., Novoplansky A., Cohen D., Plants as competing populations of redundant organs, Plant Cell Environ. 16 (1993) 765-770.

[80] Sims D., Pearcy A., Response of leaf anatomy and photosynthetic capacity in Alocasia macrorrhiza (Araceae) to a transfer from low to high light, Am. J. Bot. 79 (1992) 449-455.

[81] Smith W.K., Vogelmann T.C., Delucia E.H., Bell D.T., Shepherd K.A., Leaf form and photosynthesis, BioScience 47 (1997) 785793.

[82] Sterck F.J., Bongers F., Ontogenetic changes in size, allometry, and mechanical design of tropical rain forest trees, Am. J. Bot. 85 (1998) 266-272.

[83] Swaine M.D., Whitmore T.C., On the definition of ecological species groups in tropical rainforests, Vegetatio 75 (1988) 81-86.

[84] Terashima I., Productive structure of a leaf, in: Briggs W.R. (Ed.), Photosynthesis, Liss, New-York, 1989, pp. 207-226.

[85] Uemura A., Ishida A., Nakano T., Terashima I., Tanabe H., Matsumoto Y., Acclimation of leaf characteristics of Fagus species to previous-year and current-year solar irradiances, Tree Physiol. 20 (2000) 945-951.

[86] Valladares F., Wright S.J., Lasso E., Kitajima K., Pearcy R.W., Plastic phenotypic response to light of 16 congeneric shrubs from a Panamanian rainforest, Ecology 81 (2000) 1925-1936.

[87] Valladares F., Skillman J.B., Pearcy R.W., Convergence in light capture efficiencies among tropical forest understory plants with contrasting crown architectures: a case of morphological compensation, Am. J. Bot. 89 (8) (2002) 1275-1284.

[88] Wareing P.F., Problems of juvenility and flowering in trees, Bot. J. Linn. Soc. 56 (1959) 282-289.

[89] Whitehead D., Kelliher F.M., Frampton C.M., Godfrey M.J.S., Seasonal development of leaf area in a young, widely spaced Pinus radiata D. Don stand, Tree Physiol. 14 (1994) 1019-1038.

[90] Witkowsky E.T.F., Lamont B.B., Leaf specific mass confounds leaf density and thickness, Oecologia 88 (1991) 846-493. 